\title{
Glycoproteins from Russian Wheat Aphid Infested Wheat Induce Defence Responses
}

\author{
Mohase* Lintle and Amie J. van der Westhuizen
}

Department of Plant Sciences, University of the Free State, P.O. Box 339, Bloemfontein, 9300, Republic of South Africa. Fax: +27-(0)514488772.E-mail: mohasel@sci.uovs.ac.za

* Author for correspondence and reprint requests

Z. Naturforsch. 57c, 867-873 (2002); received April 2/May 21, 2002

Elicitors, Russian Wheat Aphid, Wheat

Elicitors are molecules which can induce the activation of plant defence responses. Elicitor activity of intercellular wash fluid from Russian wheat aphid, Diuraphis noxia (Mordvilko) infested resistant (cv Tugela DN), and susceptible (cv Tugela), wheat (Triticum aestivum L.), was investigated. Known Russian wheat aphid resistance related responses such as peroxidase and $\beta$-1,3-glucanase activities were used as parameters of elicitor activity. The intercellular wash fluid from infested resistant plants contains high elicitor activity while that from infested susceptible plants contains no or very little elicitor activity. After applying C-18 reverse phase and concanavalin A Sepharose chromatography, elicitor active glycoproteins were isolated from the intercellular wash fluid of Russian wheat aphid infested resistant wheat. The elicitor-active glycoproteins separated into three polypeptides during sodium dodecyl sulfate-polyacrylamide gel electrophoresis. The isolated glycoproteins elicited peroxidase activity to higher levels in resistant than in susceptible cultivars. It was evident that the glycoproteins were probably a general elicitor of plant origin. Information gained from these studies is valuable for the development of plant activators to enhance the defence responses of plants.

\section{Introduction}

The term 'elicitor' has been used to describe molecules that are able to induce physiological or biochemical responses associated with the expression of resistance (Kogel et al., 1988). Many elicitors are extracellular microbial products, or breakdown products from entities in the microbial or plant cell wall. Fungal cell wall elicitors include $\beta$ 1,3-glucans (Sharp et al., 1984), chitosan (Friestensky et al., 1984) and the unsaturated lipids, arachidonic and eicosapentanoic acids. A number of metabolites of microbial origin also act as elicitors, including polysaccharides (Sharp et al., 1984), galactose and mannose-rich glycoproteins (Darvil and Albersheim, 1984; Dixon, 1986), fatty acids (Bostock et al., 1981) and hydrolytic enzymes (Collmer and Keen, 1986). The numerous biotic elicitors have been found not only in germination fluid, culture filtrates, and cell walls or membranes of phytopathogenic fungi, but also in apoplastic spaces of plants (Darvill and Albersheim, 1984).

Elicitor activity has also been correlated with pectic fragments that arise from partial degradation of the plant cell wall. Degradation products of hydrolases and lyases are active, with maximum activity associated with oligomers of 7-15 units (Collmer and Keen, 1986). Many invading pathogens secrete a large arsenal of hydrolytic enzymes that digest the plant cell wall, allowing the pathogen to have access to nutrients (Salmond, 1994). Such enzymes can release plant cell wall-derived elicitors that activate defence responses (Davis et al., 1984; Hahn et al., 1981).

Russian wheat aphid (RWA) infestation has been reported to induce the hypersensitive response (HR) in barley (Belefant-Miller et al., 1994). Collapsed autofluorescent cells of the mesophyll and bundle sheath tissues in response to RWA infestation, is visually similar to the HR of barley to incompatible fungi (Belefant-Miller et al., 1994). As part of the resistance mechanism, the induction of defence related enzymes such as pathogenesis related (PR) chitinases and $\beta-1,3-$ glucanases, as well as peroxidases has been reported (Van der Westhuizen et al., 1998a, 1998b). The initial events that occur at the plant-aphid interface and trigger the defence responses have not yet been thoroughly studied. In an attempt to elucidate the signalling events in wheat plants in- 
fested with the RWA, we isolated the elicitors from the apoplastic fluid of infested wheat plants. We further determined their eliciting activity in the susceptible and resistant wheat cultivars by measuring the induced activities of known defence related enzymes.

\section{Materials and Methods}

Resistant wheat plants (Triticum aestivum L., cv Tugela DN) containing the Dn-1 gene, PI 137739, (Du Toit, 1989) for resistance to the RWA, Diuraphis noxia (Mordvilko), and susceptible plants, cv Tugela, were cultivated in trays, each containing 240 plants (120 susceptible and 120 resistant) under greenhouse conditions at temperatures of $22 \pm 4{ }^{\circ} \mathrm{C}$. Diuraphis noxia (Mordvilko) is indigenous to Southern Russia, countries bordering the Mediterranean Sea, Iran and Afghanistan (Hewitt et al., 1984). At the beginning of the third-leaf growth stage the plants were infested with the RWA, according to Du Toit's method (Du Toit, 1989). Aphids (approx. 10 aphids per plant) were scattered onto the leaves and multiplied as the plant developed, infesting emerging younger leaves.

\section{Collection and application of intercellular wash fluid (IWF)}

After $120 \mathrm{~h}$ of infestation, fresh leaves (75 g) of infested resistant and susceptible plants were harvested. The leaves were cut into $7-\mathrm{cm}$ pieces, and the cut ends rinsed in distilled water. The leaves were vacuum infiltrated in double distilled water $(100 \mathrm{ml})$ for $5 \mathrm{~min}$ and IWF was collected by centrifugation $\left(1000 \times g, 10 \mathrm{~min}, 4^{\circ} \mathrm{C}\right)$. The extraction was performed two times and the intercellular wash fluids combined. The experiment was repeated four times.

IWF from RWA infested susceptible and resistant plants was intercellularly injected into the second leaves of susceptible and resistant plants at the beginning of the third-leaf growth stage according to a slightly modified method of Hagborg (1970). The leaf was clamped between two rubber stoppers of the tongueseizing forceps and IWF (200 $\mu \mathrm{l})$ was injected into the leaf using a hypodermic syringe. Control plants were intercellularly injected with double distilled water.

\section{Enzyme activity of intercellular wash fluid}

\section{Peroxidase activity}

Total peroxidase activity of injected leaves was determined. Leaf tissue $(0.5 \mathrm{~g})$ was ground in liquid nitrogen and extracted with $2 \mathrm{ml} 100 \mathrm{~mm}$ sodium acetate buffer, pH 5.5, containing $10 \mathrm{~mm}$ mercaptoethanol, $2 \mathrm{~mm}$ ethylenediamine tetraacetic acid (EDTA) and $2 \mathrm{~mm}$ phenylmethylsulfonyl fluoride (PMSF). The extract was centrifuged $\left(12,000 \times g, 20 \mathrm{~min}, 4{ }^{\circ} \mathrm{C}\right)$ and the supernatant used as the crude enzyme. The assay mixture consisted of $500 \mu \mathrm{l} 80 \mathrm{~mm}$ potassium phosphate buffer (pH 5.5) containing 2 mM EDTA, $340 \mu \mathrm{l}$ distilled water, $100 \mu \mathrm{l} 5 \mathrm{~mm}$ guaiacol, $50 \mu \mathrm{l} 8.2 \mathrm{~mm} \mathrm{H}_{2} \mathrm{O}_{2}$ and $10 \mu \mathrm{l}$ enzyme extract. The change in absorbance at $470 \mathrm{~nm}$ was monitored spectrophotometrically for $3 \mathrm{~min}$ at $30{ }^{\circ} \mathrm{C}$ against a blank that lacked the enzyme. The activity was expressed as $\mu$ mol tetraguaiacol $\mathrm{mg}^{-1}$ protein $\mathrm{min}^{-1}$.

\section{$\beta$-1,3-glucanase activity}

A modified method of Fink et al. (1990) was used. The assay mixture contained in a final volume of $0.5 \mathrm{ml}, 10 \mu \mathrm{l}$ enzyme extract, $250 \mu \mathrm{l}$ of laminarin $\left(2 \mathrm{mg} \mathrm{ml}^{-1}\right)$ and $50 \mathrm{~mm}$ sodium acetate buffer ( $\mathrm{pH} 4.5)$. After incubation $\left(37^{\circ} \mathrm{C}, 10 \mathrm{~min}\right)$, $0.5 \mathrm{ml}$ Somogyi reagent (Somogyi, 1952) was added and the mixture heated at $100{ }^{\circ} \mathrm{C}$ for $10 \mathrm{~min}$. The mixture was cooled and $0.5 \mathrm{ml}$ of arsenomolybdate reagent of Nelson (1944) added. The absorbance of the colored product was measured at $540 \mathrm{~nm}$. A standard curve relating $A_{540}$ to glucose concentration was used to calculate enzyme activity, which was expressed as $\mu \mathrm{mol}$ glucose $\mathrm{mg}^{-1}$ protein $\mathrm{min}^{-1}$.

\section{Isolation of elicitors}

IWF $(50 \mathrm{ml})$ was freeze-dried and redissolved in $5 \mathrm{ml} \mathrm{70 \%} \mathrm{(v/v)} \mathrm{methanol.} \mathrm{An} \mathrm{aliquot} \mathrm{of} \mathrm{this} \mathrm{mix-}$ ture was fractionated using reverse phase (RP) chromatography on pre-equilibrated $(70 \%$ (v/v) methanol) C-18 Sep Pak cartridges (Waters Corporation, Milford, Massachusetts, USA). The column was eluted with $10 \mathrm{ml} 70 \%$ (v/v) methanol and all the eluent was collected as $1 \mathrm{ml}$ fractions. Each fraction was dried in vacuo at ambient temperature and redissolved in $2 \mathrm{ml}$ double distilled water. Each of these fractions was intercellularly 
injected into the second leaves of plants at the beginning of the third-leaf growth stage. Leaves from sixty plants (30 susceptible and 30 resistant) were injected and after $48 \mathrm{~h}$ of treatment harvested from ten randomly selected plants for determination of total peroxidase activity.

\section{Isolation of glycoproteins}

Glycoproteins were isolated from the peroxidase-inducing fraction recovered from RP chromatography. We modified and carried out the procedure outlined by Kogel et al., (1992). One milliliter of the fraction was passed through a concanavalin A (con A) Sepharose column (Pharmacia) equilibrated with $20 \mathrm{~mm}$ Tris(hydroxymethyl)-aminomethane- $\mathrm{HCl}, \mathrm{pH} 7.4$, containing $0.5 \mathrm{M} \mathrm{NaCl}, 1.0 \mathrm{~mm} \mathrm{MgCl}_{2}, 1.0 \mathrm{~mm} \mathrm{MnCl}_{2}$ and $1.0 \mathrm{~mm} \mathrm{CaCl}$. The column was firstly eluted with $40 \mathrm{ml}$ of $0.1 \mathrm{M}$ methyl $\alpha$-D-glucopyranoside (Sigma) and subsequently with $40 \mathrm{ml}$ of $0.5 \mathrm{M}$ methyl $\alpha$-D-mannopyranoside (Sigma). The eluent was collected and the volume reduced to $7.5 \mathrm{ml}$ using a rotavapor and then desalted on PD 10 columns (Pharmacia). The isolated glycoproteins were injected intercellularly into second leaves of sixty plants (30 susceptible and 30 resistant) at the beginning of the third-leaf growth stage. The second and third uninjected leaves were collected separately from ten randomly selected plants $48 \mathrm{~h}$ after injection for determination of total peroxidase activity.

\section{Characterization of glycoproteins}

A spot-dot assay for glycoproteins was carried out according to Hawkes (1982) and Hawkes et al. (1982). A sample of glycoproteins containing $1.5 \mu \mathrm{g}$ of proteins was applied onto a nitrocellulose membrane. The membrane was incubated for $15 \mathrm{~min}$ in blocking solution containing 3\% (w/v) milk (fat free) powder and $20 \mathrm{~mm} \mathrm{NaCl}$ in $50 \mathrm{~mm}$ Tris buffer, pH 7.4 (TBS). The blocking solution was replaced with freshly prepared Con A (50 $\mu \mathrm{g}$ $\mathrm{ml}^{-1}$, Pharmacia) in blocking solution and the membrane incubated for $30 \mathrm{~min}$. The membrane was washed in three changes of Tris-buffered saline. Horseradish peroxidase $\left(50 \mu \mathrm{g} \mathrm{ml} \mathrm{m}^{-1}\right.$, Boehringer-Mannheim) in blocking solution was added and the membrane incubated for another $30 \mathrm{~min}$. The membrane was again washed in three changes of Tris-buffered saline and stained with freshly prepared solution of $0.06 \%(\mathrm{w} / \mathrm{v})$ 4-chloro-1-naphthol and $0.01 \%(\mathrm{v} / \mathrm{v})$ hydrogen peroxide in TBS and washed in distilled water then air-dried.

\section{Sodium dodecyl sulfate polyacrylamide gel electrophoresis (SDS-PAGE)}

SDS-PAGE was carried out according to Laemmli (1970). A 12\% separating gel and a 6\% stacking gel were used. The gel was stained using Coomassie staining procedure according to Zehr et al. (1989).

\section{Protein concentration}

The protein concentration was determined according to the method of Bradford (1976) using $\gamma$-globulin as a standard.

\section{Results}

Enzyme activity of intercellular wash fluid

The IWF of infested resistant plants differentially induced peroxidase activity to higher levels in the resistant than in susceptible plants. Peroxidase activity was induced 7.2-fold over the control in the resistant plants and the level was 7.5-fold higher than in susceptible plants (Fig. 1A). The IWF of infested susceptible plants slightly induced peroxidase activity to levels higher than that of the control in both susceptible and resistant plants. The level of induction however was very low.

The IWF of infested resistant plants induced a 1.5 -fold increase in $\beta$-1,3-glucanase activity in the susceptible plants and a 1.7-fold increase in the resistant plants as compared to the controls (Fig. 1B). The IWF of infested susceptible plants induced no significant increase in $\beta$-1,3-glucanase activity in susceptible plants and a 1.2-fold increase over the control in the resistant plants.

\section{Isolation and characterization of elicitors from intercellular wash fluid}

The first fraction to elute during C-18 RP chromatography selectively induced the highest peroxidase activity in the resistant plants. A 9-fold increase in peroxidase activity was observed $48 \mathrm{~h}$ after treatment (Fig. 2).

The C-18 RP fraction which induced peroxidase activity, showed a positive reaction for the pres- 


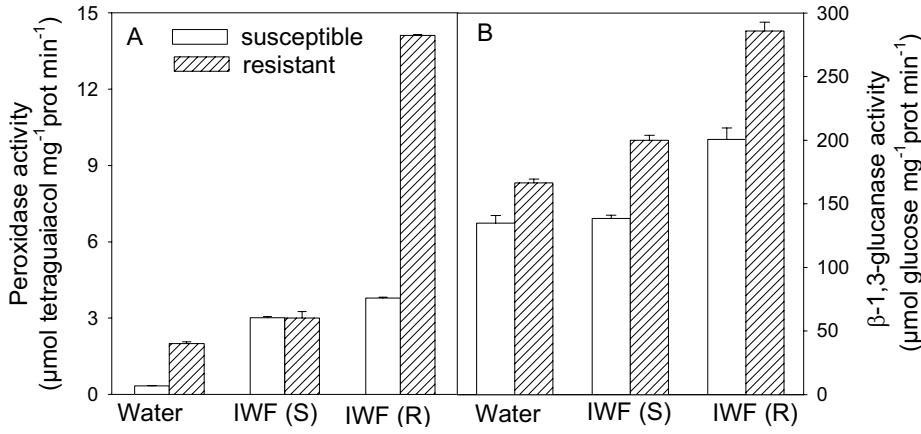

Fig. 1: Effect of intercellularly applied IWF on peroxidase activity (A) and $\beta$-1,3-glucanase activity (B) of susceptible and resistant plants $48 \mathrm{~h}$ after application. The values are means $\pm \mathrm{SD}(n=3)$. IWF $(\mathrm{S})$ : IWF originating from RWA infested susceptible plants; IWF (R): IWF originating from RWA infested resistant plants.

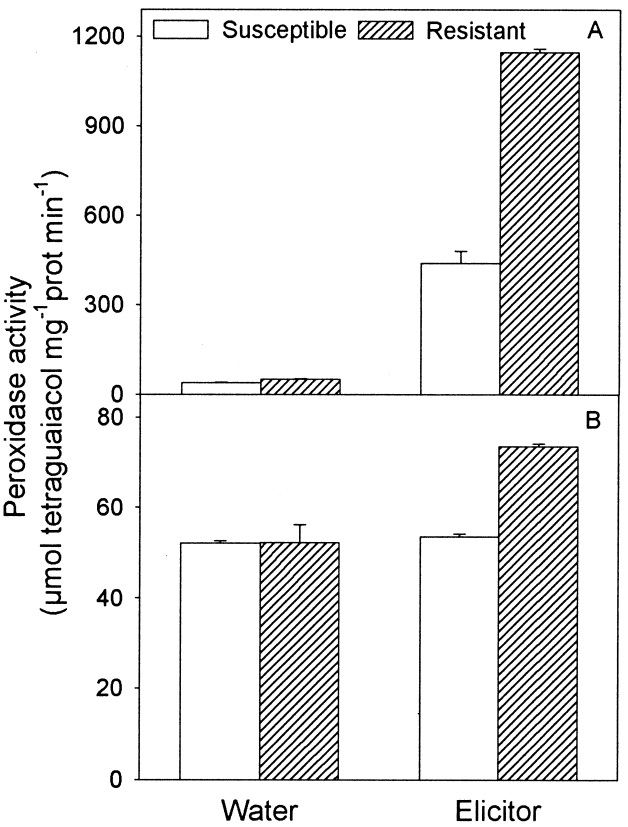

Fig. 3: Effect of intercellularly applied glycoproteins (elicitor) isolated by con A binding chromatography on peroxidase activity of susceptible and resistant wheat cultivars. The glycoproteins were intercellularly injected into second leaves and peroxidase activity determined $48 \mathrm{~h}$ after injection. The values are means $\pm \mathrm{SD}(n=3)$. A: $2^{\text {nd }}$ leaves; B: $3^{\text {rd }}$ uninjected leaves.

glycoproteins differentially induced peroxidase tivity to higher levels in the resistant than in susceptible plants (Fig. 3A). In the resistant plants the degree of induction was 22 -fold whereas in the susceptible ones it was 11 -fold. This glycoproteincontaining fraction also systemically induced peroxidase activity to higher levels in the resistant than in susceptible plants. The degree of induction was 1.4-fold. In the susceptible plants there was no induction in peroxidase activity (Fig. 3B).

After protein concentration determination, the glycoprotein-containing fraction was separated by SDS-PAGE and three polypeptides with molecu- lar masses of $41 \mathrm{kDa}, 37 \mathrm{kDa}$ and $17 \mathrm{kDa}$ were observed (results not shown).

\section{Discussion}

Russian wheat aphids are phloem feeders using their stylets to probe intercellularly before the phloem is penetrated (Fouché et al., 1984). The local events in the immediate zone of stylet entry may trigger systemic responses. Many signals orig- 
inate in the apoplast to elicit defence responses locally and systemically (Ouchi and Oku, 1981). Furthermore, it is the site where many defence related products accumulate (Bowles, 1990). During feeding, the aphids excrete a salivary phytotoxin, which was identified as a polypeptide in a preliminary study by Brigham (1992). In addition, it is suggested that the aphids may digest the cell walls as they probe the intercellular spaces (Collmer and Keen, 1986), and the cell wall fragments may act as elicitors. These products accumulate in the intercellular spaces and consequently we expected potential elicitors to occur in the intercellular wash fluids of RWA infested wheat plants.

Peroxidases and $\beta-1,3$-glucanases are involved in several defence-related responses that occur in the extracellular matrix in plants (Bowles, 1990). Van der Westhuizen et al. (1998a, 1998b) related enhanced peroxidase and $\beta$-1,3-glucanase activities to the resistance response in wheat to the RWA. Mainly peroxidase activity was therefore used in this study as a measure of eliciting capacity.

The IWF of infested resistant plants differentially induced peroxidase and $\beta$-1,3-glucanase activities to higher levels in the resistant than susceptible plants (Figs. 1A and B). The IWF of infested susceptible plants had very little of this inducing capacity, suggesting the absence of, or difference in specificity of the potential elicitor. This might also be an indication that the potential elicitor is of plant origin. These results implicate the presence of an elicitor in at least the IWF of infested resistant wheat which induced a resistance response similar to RWA infestation (Van der Westhuizen et al., 1998a, 1998b).

The fact that the magnitude of the elicitorinduced responses was considerably lower in the susceptible than resistant plants (Figs. 1A and B) may be ascribed to poor recognition of the elicitor and/or the presence of suppressors. Signal perception seems to rely on the presence of specific receptors in the plant cell, being localized either on the cell surface (Ebel and Scheel, 1997) or within the cell wall (Zehr et al., 1989, Van den Ackerveken et al., 1996), which initiate signalling processes that activate plant defences. High-affinity receptor-like binding proteins which bind a glucan elicitor from $P$. megasperma have been found in plasma membrane-enriched fractions from soybean roots (Schmidt and Ebel, 1987).
Different chromatographic techniques were used to isolate the potential elicitor. An elicitor active fraction eluted early from the C-18 RP column, illustrating its polar nature (Fig. 2). It additionally contains lectin (Con A)-binding compounds, supposingly glycoproteins. The glycoproteins, isolated from the elicitor active C-18 RP fraction by Con A-binding chromatography, contained elicitor activity (Figs. 3A and B), confirming the glycoprotein nature of the elicitor. SDSPAGE of this glycoprotein revealed three bands (results not shown). The glycoprotein elicitor, like RWA infestation (Van der Westhuizen et al., 1998b), induced peroxidase activity systemically (Fig. 3B). Systemic responses have been implicated in plant-wound, plant-pathogen and plantnematode interactions (Bowles, 1990).

The Con A-bound glycoproteins were eluted with methyl $\alpha$-D-mannopyranoside and methyl $\alpha$-D-glucopyranoside suggesting that the elicitor may have either mannose or glucose residues as its carbohydrate moiety.

The role of lectin-binding glycoproteins as inducers of non-host resistance in cereals has previously been reported in wheat by Kogel et al. (1988). The glycoprotein elicitor from germ tube walls of Puccinia graminis f. sp. tritici induced a non-specific induction of defence responses. Kogel et al. (1991) reported the presence of specific binding sites for a glycoprotein elicitor in wheat membranes, of which the majority are located in the plasma membrane. Race-cultivar specificity of elicitor binding was not observed since the glycoprotein elicitor bound equally well to plasma membranes from the near-isogenic Prelude wheat lines which differ at the $S r 5$ locus.

The lectin-binding glycoproteins may not be the only elicitors in the IWF of the RWA infested wheat plants, even though the presence of other elicitors was not investigated. Cell wall glucans and mannose-containing polysaccharides, arising from Colletotrichum lindemuthianum have been reported as elicitors in bean cells (Tepper and Anderson, 1986). The fatty acids, arachidonic and eicosapentaenoic acids, originating from Phytophthora infestans, elicited the accumulation of phytoalexins in potato tubers (Bloch et al., 1984). Interactions may occur among different elicitors to modify the elicitor potential. Fungal cell wall elicitors and pectic fragments of plant origin act 
synergistically in legumes (Davis et al., 1986) as well as the glucan elicitor and the agrichemical probenazole in rice (Dixon and Lamb, 1990).

Belefant-Miller H., Porter D.-R., Pierce M.-L. and Mort A.-J. (1994), An early indicator of resistance in barley to Russian wheat aphid. Plant Physiol. 105, 1289-1294.

Bloch C.-V., De Wit P.-J.-G.-M. and Kuc J. (1984), Elicitation of phytoalexins by arachidonic and eicosapentanoic acids: a host survey. Physiol. Plant Pathol. 25, 199-208.

Bostock R.-M., Kuc J.-A. and Laine R.-A. (1981), Eicosapentaenoic and arachidonic acids from Phytophthora infestans elicit fungitoxic sesquiterpenes in potato. Science 212, 67-69.

Bowles D.-J. (1990), Defense related proteins in higher plants. Annu. Rev. Biochem. 59, 873-907.

Bradford M.-M. (1976), A rapid and sensitive method for the quantitation of microgram quantities of protein utilizing the principle of protein-dye binding. Anal. Biochem. 72, 248-254.

Brigham D.-L. (1992), Chemical ecology of the Russian wheat aphid: the influence of surface wax on host selection, and the isolation of the salivary phytotoxin. In: Proceedings Fifth Russian Wheat Aphid Conference, Jan 26-28, Fortworth, Texas.

Collmer A. and Keen N.-T. (1986), The role of pectic enzymes in plant pathogenesis. Annu. Rev. Phytopathol. 24, 383-409.

Darvill A.-G. and Albersheim P. (1984), Phytoalexins and their elicitors in defense against microbial infections in plants. Annu. Rev. Plant Physiol. 35, 243-275.

Davis K.-R., Lyod G.-D., Darvil A.-G. and Albersheim P. (1984), Host-pathogen Interactions. XXV. Endopolygalacturonic acid lyase from Erwinia carotovora elicits phytoalexin accumulation by releasing plant cell wall fragments. Plant Physiol. 74, 52-60.

Davis K.-R., Darvil A.-G. and Albersheim P. (1986), Host-pathogen interactions XXXXI. Several biotic and abiotic elicitors act synergistically in the induction of phytoalexin accumulation in soybean. Plant Mol. Biol. 6, 23-32.

Dixon R.-A. (1986), The Phytoalexin response: elicitation, signaling and the control of host gene expression. Biol. Rev. 61, 231-291.

Dixon R.-A. and Lamb C.-J. (1990), Molecular interactions between plants and microbial pathogens. Annu. Rev. Plant Physiol. Plant Mol. Biol. 41, 339-367.

Du Toit F. (1989), Another source of Russian wheat aphid (Diuraphis noxia) resistance in Triticum aestivum. Cereal Res. Commun. 16 (1-2), 105-106.

Ebel J. and Scheel D. (1997), Signals in host-parasite interaction. In: The Mycota V, part A, Plant Relationships (G. C. Carrol, and P. Tudzynski, eds.). Springer, Berlin, Heidelberg (pp. 85-105).

\section{Acknowledgements}

We gratefully acknowledge the financial support granted by the Foundation for Research Development and the University of the Free State.

Fink W., Liefland M. and Memdgen K. (1990), Chitinases and $\beta$-1,3-glucanases in the apoplastic compartment of oat (Avena sativa L.). Plant Physiol. 88, 270-275.

Fouché A., Verhoeven R.-L., Hewitt P.-H., Walters M.C., Kriel C.-F. and DeJager J. (1984), Russian aphid (Diuraphis noxia) feeding damage on wheat, related cereals and a Bromus grass species. In: Progress in Russian Wheat Aphid (Diuraphis noxia Mordv), Research in the Republic of South Africa (M.-C. Waters, ed.). Technical communication No.191, Department of Agriculture, Johannesburg, Republic of South Africa, pp. 22-33.

Friestensky B., Riggleman R.-C., Wagoner W. and Hadwiger L.-A. (1984), Gene expression in susceptible and disease resistant interactions of peas induced with Fusarium solani pathogens and chitosan. Physiol. Plant Pathol. 27, 15-28.

Hagborg W.-A.-F. (1970), A device for injecting solutions into thin leaves of plants. Can. J. Botany 48, $1135-1136$.

Hahn M.-G., Darvil A.-G. and Albersheim P. (1981), Host-pathogen Interactions XIX. The endogenous elicitor, a fragment of a plant cell wall polysaccharide that elicits phytoalexin accumulation in soybeans. Plant Physiol. 68, 1161-1169.

Hawkes R. (1982), Identification of concanavalin Abinding proteins after sodium dodecyl sulfate-gel electrophoresis and protein blotting. Anal. Biochem. 123, $143-146$.

Hawkes R., Niday E. and Gordon J. (1982), A dot-immunoblotting assay for monoclonal and other antibodies. Anal. Biochem. 119, 142-147.

Hewitt P.-H., Van Niekerk, G.-J.-J., Walter M.-C., Kriel C.-F. and Fouchè A. (1984), Aspects of the ecology of the Russian Wheat Aphid, Diuraphis noxia, in the Bloemfontein District. I. the colonization and infestation of sown wheat, identification of summer hosts and cause of infestation symptoms. In: Progress in Russian Wheat Aphid (Diuraphis noxia Mord.). Research in the Republic of South Africa. Proceedings of a meeting of the Russian Aphid Task team held at the University of the Orange Free State, Bloemfontein 5-6 May 1982 (M. C. Walters, ed.). Technical Communication No 191, Department of Agriculture, Republic of South Africa.

Kogel G., Beißman B., Reisener H.-J. and Kogel K.-H. (1988), A single glycoprotein from Puccinia graminis f. sp. tritici cell walls elicits the hypersensitive lignification response in wheat. Physiol. Mol. Plant Pathol. 33, $173-185$. 
Kogel G., Beissman B., Reisener H.-J. and Kogel K. (1991), Specific binding of a hypersensitive lignification elicitor from Puccinia graminis f. sp. tritici to the plasma membrane from wheat (Triticum aestivum L.). Planta 183, 164-169.

Kogel K., Beißman B., Engels W., Marticke K.-H. and Reisener H.-J. (1992), Elicitor active glycoproteins in apoplastic fluids of stem rust infected wheat leaves. Physiol. Plant Pathol. 40, 79-89.

Laemmli U.-K. (1970), Cleavage of structural proteins during assembly of bacteriophage T4. Nature. 227, $680-685$.

Nelson N. (1944), A photometric adaptation of the Somogyi method for the determination of glucose. J. Biol. Chem. 153, 375-380.

Ouchi S. and Oku H. (1981), Susceptibility as a process induced by pathogens. In: Plant Disease Control (R. C. Staples and G. H. Toeniessen, eds). Wiley, New York (pp. 33-34).

Salmond G.-P.-C. (1994), Secretion of extracellular virulence factors by plant pathogenic bacteria. Annu. Rev. Phytopathol. 32, 181-200.

Sharp J.-K., Albersheim P., Ossowski P., Pilotti A., Garegg P. and Lindberg B. (1984), Comparison of the structures and elicitor activities of a synthetic and a mycelial-wall derived hexa-( $\beta$-D-glucopyranosyl)-Dglucitol. J. Biol. Chem. 259, 11341-11345.
Schmidt W.-E. and Ebel J. (1987), Specific binding of a fungal glucan phytoalexin elicitor to membrane fractions from soybean Glycine max. Proc. Natl. Acad. Sci. USA. 84, 4117-4121.

Somogyi M. (1952), Notes on sugar determination. J. Biol. Chem. 195, 19-23.

Tepper C.-S. and Anderson J.-A. (1986), Two cultivars of bean display a differential response to extracellular components from Colletotrichum lindemuthinum. Physiol. Mol. Plant Pathol. 29, 411-420.

Van den Ackerveken G., Marios E. and Bonas U. (1996), Recognition of the bacterial avirulence protein AvrBs3 occurs inside the host plant cell. Cell 87, $1307-1316$.

Van der Westhuizen A.-J., Qian X.-M. and Botha A.-M. (1998a), $\beta$-1,3-glucanases in wheat and resistance to the Russian Wheat Aphid. Physiol. Plant. 103, 125131.

Van der Westhuizen A.-J., Qian X.-M. and Botha A.-M. (1998b), Differential induction of apoplastic peroxidase and chitinase activities in susceptible and resistant wheat cultivars by Russian Wheat Aphid infestation. Plant Cell Rep. 8, 132-137.

Zehr B.-D., Savin T.-J. and Hall R.-E. (1989), A one-step low background Coomassie staining procedure for polyacrylamide gels. Anal. Biochem. 82, 157-159. 